\title{
Shifting Sands
}

\section{A Social and Environmental History of Los Angeles's Beaches, 1920s-1970s}

\begin{abstract}
N 1965, BRITISH architectural historian Reyner Banham learned how to drive in order to explore Los Angeles. He was drawn to L.A. for its unconventional urban configuration and iconic architecture. Many rides and several years later, Banham published a landmark study of the urban region that began with the beaches, which, he wrote, were "what other metropolises should envy in Los Angeles." Why did Banham begin a description of what was then the third-largest city in the United States with the beach? One reason was that Los Angeles's scattered pattern of development ruled out a chronological examination of the built environment that would start with the city's downtown. More significantly, Banham argued that Los Angeles was "the greatest City-on-the-Shore in the world." ${ }^{2}$ My project shows how Los Angeles came to earn that prestige.

Between the I920s and the I96os, engineers, city officials, urban planners, and the business elite worked together to transform the relatively untouched beaches of the early twentieth century into modern playgrounds. They cleaned up and enlarged the beaches-up to three times their original size—and destroyed old piers and barracks to make room for brand-new accommodations, parking lots, and freeways. The members of this powerful "beach lobby" reinvented the beach experience for the suburban age, effectively preventing a much-feared "white flight" from the coast. In doing so, they established southern California as the national reference point for shoreline planning and public access to the coast. Yet these transformations also had adverse consequences for certain groups of beachgoers, including African Americans, gay men and women, and bodybuilders, whose presence on the sand did not fit what the beach lobby had in mind for the shores. These Angelenos claimed their right to occupy the coastline, fighting with marginal success against the currents of beach modernization.
\end{abstract}

California History, Vol. 93, Number 2, pp. 61-63, ISSN 0162-2897, electronic ISSN 2327-1485. (C) 2016 by the Regents of the University of California. All rights reserved. Please direct all requests for permission to photocopy or reproduce article content through the University of California Press's Reprints and Permissions web page, http://www.ucpress.edu/journals.php?p=reprints. DOI: $10.1525 / \mathrm{CH} .2016 .93 .2 .61$. 
Considering the beaches as urban spaces that warranted careful planning and policing extends a vast scholarship on the rise of modern beach resorts in the United States, from Coney Island to Atlantic City. An urban historical viewpoint also draws in the environmental consequences of the twentieth-century beach-bathing boom, which henceforth has been explored predominantly in social terms. By examining the Los Angeles beaches not only as tourist attractions but also as multidimensional urban spaces, I break with predominant historical accounts of twentieth-century American cities, which usually focus on the downtown or suburbs. Turning away from the streets and toward the city's edges not only uncovers how L.A.'s beaches were quite literally constructed, but also shows the peculiar trajectory of a public space that remained popular throughout the twentieth century despite persistent racial tensions.

The beaches of metropolitan Los Angeles were the subject of intense debates among the engineering, scientific, and urban planning communities. They also were an important aspect of daily life for most Angelenos. For the rest of the nation, the beaches were spaces of fantasy, projected on the silver and small screens and evoked in popular songs. Examining the public's love affair with the beach in the twentieth century thus requires looking at a wide range of data, from engineering reports to popular literature, oral interviews, municipal archives, films, photographs, and urban planning documents.

These diverse sources show how, in the I920s, rapid demographic growth, the widespread adoption of the car, and the beach real estate boom turned the region's beaches into urban spaces, visited daily by large and diverse crowds. As such, beaches generated heated debates with respect to their development, accessibility, policing, and racial segregation. In the I930s, ill-advised coastal constructions caused erosion, which, along with other environmental threats and the rampant privatization of the shores, led to the formation of a beach lobby of businesspeople, city officials, and engineers and scientists interested in coastal issues. During the I940s, these men produced reports and studies lamenting the sad state of the shores and also planning the ideal urban beach. The Second World War worsened the so-called beach crisis, as sea bathing was not perceived as a necessity in the war context. Yet the war also gave a boost to the beach modernization proponents, who argued, following city planner Robert Moses's example, that beaches should "take their place alongside highways, buildings, and other public works" ${ }^{3}$ in the postwar construction programs. Their wishes were fulfilled in the following years, when - thanks to lobbying efforts at the state level—multiple beach modernization projects were undertaken in the region while the proportion of the metropolitan coastline accessible to the public increased steadily.

The central tenets of the beach lobby were profoundly challenged in the late ig6os, under the triple pressure of the modern environmentalist movement, the rise of an anti-public beach sentiment among coastal homeowners, and controversy between developers and local residents over oceanside high-rises. While the push for beach modernization lasted only a few years, it had a deep impact on who had "the right to the beach." ${ }^{4}$ The consequences were especially visible on the sands of south Santa Monica. Previously a haven for gay, black, and working-class beachgoers, an alliance of real estate interests and city officials combined planning and policing strategies to turn this popular beach into a semi-privatized playground for the white middle class. By building "the 


\section{NOT CONEY ISLAND - BUT SANTA MONICA ON A HOT SUNDAY}

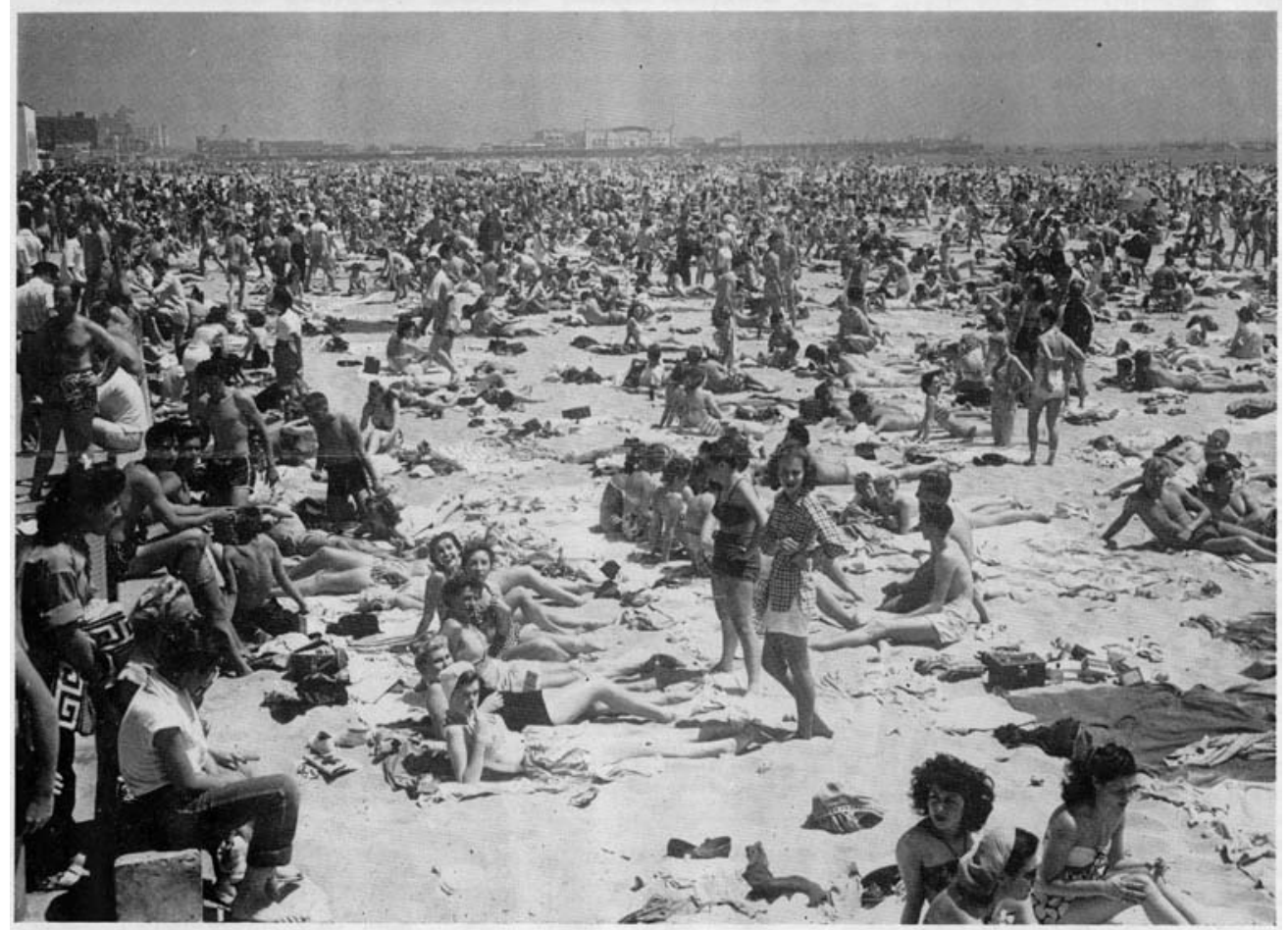

This section of Santa Monica beach is known as "Roadside Rest" and is especially popular with teenagers. All the facilities that should be present to care for a crowd of this size-access roads, parking oreas, sanitary focilities, bathhouses, sport and playgame areas-are sadly deficient. Better than all the words in Webster, this photograph proves that beach development in Los Angeles County, as elsewhere,
is an immediate, pressing problem.

This picture was published in August 1949 in the monthly bulletin of the Shoreline Planning Association, an organization dedicated to the preservation and development of California's beaches. The comparison with Coney Island, famous for its huge crowds, was meant to alert the state's inhabitants to the dire situation of the beaches. Moreover, by picturing semi-naked teenagers in close proximity at a moment when juvenile delinquency was a hot topic among parents and politicians, the association suggested that dirty and crowded beaches contributed to premarital sex and delinquent behavior in general. California Coast 3 , no. 3 (August 1949): 3.

Courtesy Morrough P. O’Brien Papers, box 14, item 101, Water Resources Collection and Archives, UC Riverside.

greatest City-on-the-shore," the beach lobby shifted the sands toward social and racial exclusion in Los Angeles's largest public space.

\section{NOTES}

I. Reyner Banham, Los Angeles: The Architecture of Four Ecologies (Berkeley: University of California Press, first ed. I97I; 2009), I9.

2. Ibid.

3. Robert Moses, "Post-war Beach Problems," Shore \& Beach, no. 2 (October I943): 36.

4. See Don Mitchell's work on the politics of public space in the United States. He himself borrows the phrase "the right to the city" from French geographer Henri Lefebvre. Don Mitchell, The Right to the City: Social Justice and the Fight for Public Space (New York: Guilford Press, 2003); Henri Lefebvre, Le Droit à La Ville, I (Paris: Anthropos, I968). 